\title{
Administration of low dose of glucose suppresses catabolism under general anaesthesia maintained with remifentanil
}

\author{
Shinichiro Yoshimura ${ }^{1 *}$, Maiko Tomita ${ }^{1}$, Nobuyoshi Kusama ${ }^{1}$, Hiroyuki Hirate ${ }^{1}$, Takeshi Sugiura', Takafumi Azami² and Kazuya Sobue
}

*Correspondence: s.yoshimura0829@gmail.com

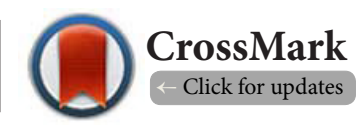

'Department of Anesthesiology and Medical Crisis Management, Nagoya City University Graduate School of Medical Sciences, Nagoya, Japan.

${ }^{2}$ Department of Pathophysiology (Anesthesiology), Nagoya City University School of Nursing, Nagoya, Japan.

\begin{abstract}
Background: The aim of this prospective randomized controlled study was to examine the optimal rate of glucose administration for preventing catabolism under general anaesthesia maintained with remifentanil.

Methods: Forty-five consecutive patients who were scheduled to undergo elective head and neck surgery were enrolled. The patients were divided into three groups and were treated with a glucose-free solution (Group G0) or a glucose solution at a rate of $0.07 \mathrm{~g} / \mathrm{kg} / \mathrm{h}$ (Group G1) or $0.14 \mathrm{~g} / \mathrm{kg} / \mathrm{h}$ (Group G2). The patients' plasma glucose, the plasma levels of ketone bodies, free fatty acids (FFA), 3-methylhistidine (3$\mathrm{MH}$ ), creatinine (Cr), Branched-Chain Amino Acid (BCAA), and stress hormones were measured every two hours until $6 \mathrm{~h}(\mathrm{~T} 6)$.

Results: The plasma glucose levels of Group G2 were significantly higher than those of the other groups at T2, T4, and T6 $(\mathrm{P}<0.01)$; however, the plasma glucose levels of the three groups did not differ at POD1. Group Go exhibited significantly higher plasma ketone body and BCAA levels (at T2, T4, and T6) and FFA levels (at T4 and T6). No significant inter-group differences in the plasma levels of 3-MH/Cr or stress hormones were observed.
\end{abstract}

Conclusions: Intraoperative glucose administration at a rate of $0.07 \mathrm{~g} / \mathrm{kg} / \mathrm{h}$ under general anaesthesia inhibited catabolism without the risk of hyperglycaemia.

Keywords: Intraoperative nutrition, glucose, metabolism, remifentanil

\section{Introduction}

Some previous studies have shown that the administration of glucose during surgery can inhibit starvation-induced catabolism [1-7] and attenuate post-operative insulin resistance [8]. Furthermore, the degree of postoperative insulin resistance was found to be an independent factor associated with the length of the postoperative hospital stay [9]. However, the rate of glucose administration differed in these previous studies $(0.07-0.25 \mathrm{~g} / \mathrm{kg} / \mathrm{h})$, and hyperglycaemia occurred in most of the studies as a complication. Hyperglycaemia is known to contribute to neuronal injury [10] and to increase the risk of surgical site infection [11] it is also reportedly associated with increased morbidity and mortality at the time of acute brain injury [12].

In addition, the glucose levels of the subjects in these previous studies might have been relatively high because the general anaesthesia was maintained with fentanyl instead of remifentanil, which is better at preventing hyperglycaemia as it can effectively control intraoperative stress $[13,14]$. Furthermore, the types of surgery performed varied between the studies, with differences in the invasiveness of the procedures and, hence, in the extent of the intraoperative stress that was induced. Because of the heterogeneity in the rate of glucose administration or the degree of intraoperative stress, the most appropriate intraoperative glucose administration rate remains unknown in situations with controlled invasiveness where surgery is performed under contemporary methods of anaesthesia.

In this study, to examine the optimal rate and the effects of glucose administration under general anaesthesia maintained with remifentanil, we investigated the metabolic parameters of patients while receiving treatment with glucose at different rates.

(C) 2017 Yoshimura et al; licensee Herbert Publications Ltd. This is an Open Access article distributed under the terms of Creative Commons Attribution License (http://creativecommons.org/licenses/by/3.0). This permits unrestricted use, distribution, and reproduction in any medium, provided the original work is properly cited. 
Yoshimura et al. Journal of Anesthesiology \& Clinical Science 2017,

http://www.hoajonline.com/journals/pdf/2049-9752-6-1.pdf

doi: $10.7243 / 2049-9752-6-1$

\section{Methods}

This single-centre, prospective randomized controlled study was conducted at Nagoya City University Hospital during the period from February 2013 to February 2014. The study was approved by the research ethics committee at Nagoya City University and was registered at the University Hospital Medical Information Network (UMIN) Clinical Trials Registry.

Consecutive patients (American Society of Anesthesiologists physical status I - II) who underwent elective head and neck surgery were enrolled. All the patients were enrolled after providing informed consent. The patients were randomly allocated to one of the following three groups using an envelope-based method: Group G0, which consisted of 15 patients who were infused with bicarbonate Ringer's solution without glucose; Group G1, which consisted of 15 patients who were infused with bicarbonate Ringer's solution and were treated with glucose at a rate of $0.07 \mathrm{~g} / \mathrm{kg} / \mathrm{h}(0.28 \mathrm{kcal} /$ $\mathrm{kg} / \mathrm{h}$ ) ; and Group G2, which consisted of 15 patients who were infused with bicarbonate Ringer's solution and were treated with glucose at a rate of $0.14 \mathrm{~g} / \mathrm{kg} / \mathrm{h}(0.56 \mathrm{kcal} / \mathrm{kg} / \mathrm{h})$ The exclusion criteria consisted of patients who were less than 20 years of age or who were more than 80 years of age; those who had liver disease, chronic or acute kidney disease, chronic obstructive pulmonary disease, or diabetes; or those who were obese $\left(\mathrm{BMI}>30 \mathrm{~kg} / \mathrm{m}^{2}\right)$.

Upon arrival in the operating room, the standard monitoring of each patient's vital parameters and the bispectral index (BIS XP; Aspect Medical, DeMeern, The Netherlands) was initiated. Each patient's systolic blood pressure (BP), diastolic BP, and heart rate were evaluated using an automatic blood pressure machine every 150 seconds beginning after the start of general anaesthesia induction until the start of the operation. The patients were given $100 \%$ oxygen through a facemask for $3 \mathrm{~min}$. General anaesthesia was induced through the intravenous administration of propofol via target-controlled infusion at a concentration of 3 or $4 \mu \mathrm{g} / \mathrm{ml}$ combined with 2-4 $\mu \mathrm{g} / \mathrm{kg}$ fentanyl, $0.25-0.3 \mu \mathrm{g} / \mathrm{kg} / \mathrm{min}$ remifentanil, and $0.9 \mathrm{mg} /$ $\mathrm{kg}$ rocronium, which were delivered via tracheal intubation. After the induction of anaesthesia, the patients were given $40 \%$ oxygen, and the end-tidal carbon dioxide pressure was maintained at between 30 and $40 \mathrm{mmHg}$ by mechanical ventilation with volume control ventilation, the tidal volume was kept at $8-10 \mathrm{ml} / \mathrm{kg}$, and the positive end-expiratory pressure was kept at zero. The doses of the anaesthetic agents were adjusted to produce a BIS value of $40-60$. A 20-G or $22-\mathrm{G}$ arterial catheter was inserted into the left or right radial artery and was connected to a FloTrac/Vigileo system (Edwards Lifesciences, LLC, Irvine, CA), which enabled the continuous monitoring of stroke volume, stroke volume variation (SVV), cardiac output, and the cardiac index via a FloTracTM pressure transducer.

All the patients were infused with bicarbonate Ringer's solution, and the infusion rate was freely adjusted to obtain an SVV value of 10-15. The patients in Group G1 were infused with acetated Ringer's solution and 5\% glucose at a rate of 1.4 $\mathrm{ml} / \mathrm{kg} / \mathrm{h}$ (glucose: $0.07 \mathrm{~g} / \mathrm{kg} / \mathrm{h}$ ) and acetated Ringer's solution without glucose at a rate of $1.4 \mathrm{ml} / \mathrm{kg} / \mathrm{h}$, while the Group G2 patients were infused with acetated Ringer's solution and $5 \%$ glucose at a rate of $2.8 \mathrm{ml} / \mathrm{kg} / \mathrm{h}$ (glucose: $0.14 \mathrm{~g} / \mathrm{kg} / \mathrm{h}$ ). The Group G0 patients were infused with acetated Ringer's solution without glucose at a rate of $2.8 \mathrm{ml} / \mathrm{kg} / \mathrm{h}$. This infusion protocol was continued until the end of surgery.

\section{Measurements}

Blood samples were collected from the radial artery. The plasma glucose levels were measured every other hour from anaesthetic induction (T0) until $6 \mathrm{~h}$ (T6) as well as at $7 \mathrm{AM}$ the following morning (POD1) using an ABL800 FLEX blood gas analyser (Radiometer, Tokyo, Japan). The plasma levels of ketone bodies (acetoacetate and beta hydroxybutyrate), free fatty acids (FFA), 3-methylhistidine (3-MH), creatinine ( $\mathrm{Cr}$ ), BCAA, adrenaline, noradrenaline, cortisol, and adrenocorticotropic hormone (ACTH) were measured at $\mathrm{T} 0, \mathrm{~T} 2, \mathrm{~T} 4$, and T6.BCAA The plasma levels of ketone bodies, FFA, and $\mathrm{Cr}$ were measured using enzymatic techniques, whereas the plasma levels of BCAA, 3-MH and catecholamine were measured using high-performance liquid chromatography. The plasma ACTH levels were measured using an electro-chemiluminescence immunoassay, and the plasma cortisol levels were measured using a radioimmunoassay.

\section{Analysis}

The Statistical Package for the Social Sciences (Sigma Plot 12.5, San Jose, California, USA) was used for the statistical analyses. Data are presented as the mean (standard deviation) values. Numerical data, including those for the blood samples were compared among the three groups using a two-way repeated measure ANOVA. Categorical data were analysed using the $C$ i square test. For all the analyses, $P$ values of less than 0.05 were considered significant.

\section{Results}

Forty-six patients who underwent elective surgery were enrolled in this study. One patient refused to participate in the study. No significant differences were observed among the three groups in terms of their demographic, intraoperative data or the type of surgery that was performed (Table 1).

The subjects' stress hormones levels at T0, T2, T4, and T6 did not differ significantly among the three groups (Table 2).

The variations in the plasma levels of ketone bodies, FFA and BCAA differed significantly among the three groups ( $P$ $<0.001, P<0.05, P<0.001$, respectively, Figures $1-3$ ) and those levels of Group $\mathrm{G} 0$ was significantly higher than those of Groups $\mathrm{G} 1$ and $\mathrm{G} 2$. The change in the plasma 3-MH/Cr ratio did not differ significantly among the three groups (Figure 4).

Figure 5 shows the change in the plasma glucose level. The variations in the plasma glucose level differed significantly among the three groups $(P<0.001)$. In Group G2, the plasma glucose level was significantly higher than those of Groups $\mathrm{G} 0$ 
Table 1. Comparison of demographic and intraoperative information among the three groups.

\begin{tabular}{llll}
\hline & Group G0 & Group G1 & Group G2 \\
\hline Age (years) & $49.6(13.9)$ & $52.3(11.9)$ & $53.5(15.8)$ \\
Height $(\mathrm{cm})$ & $163.0(7.5)$ & $159.0(8.0)$ & $165.4(8.3)$ \\
Weight $(\mathrm{kg})$ & $60.1(10.1)$ & $57.7(8.0)$ & $63.6(12.0)$ \\
Body-mass index $(\mathrm{kg} / \mathrm{m})$ & $22.5(2.4)$ & $22.7(1.7)$ & $23.1(2.8)$ \\
Sex (male/female) & $9 / 6$ & $5 / 10$ & $11 / 4$ \\
Fasting time $(\mathrm{h})$ & $13.6(0.3)$ & $13.4(0.4)$ & $13.6(0.7)$ \\
Propofol (mg kg/h) & $6.7(1.4)$ & $6.2(1.0)$ & $6.2(1.1)$ \\
Remifentanil (mg kg/h) & $0.15(0.05)$ & $0.15(0.05)$ & $0.13(0.05)$ \\
Anaesthesia time (min) & $644.9(259.5)$ & $605.6(223.3)$ & $552.2(162.5)$ \\
Infusion balance (mL) & $2359.5(1379.2)$ & $1899.2(807.2)$ & $2285.3(1415.5)$ \\
\hline Type of surgery & & & \\
\hline Brain tumour surgery & 4 & 4 & 5 \\
Head and neck tumour surgery & 8 & 8 & 3 \\
Cerebral bypass surgery & 1 & 2 & 2 \\
Neurovascular decompression & -- & 1 & 1 \\
Tympanoplasty & -- & -- & 1 \\
Clipping of a cerebral aneurysm & 1 & -- & 2 \\
Carotid endarterectomy & 1 & -- & \\
\hline
\end{tabular}

Values are given as the mean (SD) or number.

No significant differences were observed among the groups.

Table 2. Comparison of plasma adrenaline, noradrenaline, cortisol, and ACTH levels.

\begin{tabular}{llllll}
\hline & & T0 & T2 & T4 & T6 \\
\hline ACTH $(\mathrm{pg} / \mathrm{ml})$ & G0 & $17.3(14.0)$ & $5.2(13.4)$ & $8.2(15.6)$ & $11.6(32.5)$ \\
& G1 & $18.6(20.4)$ & $2.9(2.5)$ & $2.7(2.1)$ & $3.1(2.8)$ \\
& G2 & $11.8(10.0)$ & $2.7(2.7)$ & $3.2(2.4)$ & $2.9(2.4)$ \\
\hline Adrenaline $(\mathrm{pg} / \mathrm{ml})$ & G0 & $9.5(8.7)$ & $57.4(30.0)$ & $19.4(13.0)$ & $19.3(19.7)$ \\
& G1 & $8.8(6.7)$ & $65.5(46.5)$ & $20.2(13.1)$ & $14.8(19.5)$ \\
& G2 & $10.6(7.6)$ & $47.0(37.7)$ & $17.8(11.1)$ & $10.9(9.5)$ \\
\hline Noradrenaline $(\mathrm{pg} / \mathrm{ml})$ & $\mathrm{G} 0$ & $95.0(58.5)$ & $60.7(33.8)$ & $63.7(57.8)$ & $58.5(55.8)$ \\
& G1 & $73.5(58.0)$ & $50.5(30.9)$ & $41.8(26.6)$ & $38.9(18.5)$ \\
& G2 & $120.9(73.7)$ & $95.9(97.1)$ & $65.0(75.3)$ & $65.8(56.8)$ \\
\hline Cortisol $(\mu \mathrm{gg} / \mathrm{d})$ & $\mathrm{G} 0$ & $12.6(11.1)$ & $6.0(9.7)$ & $3.5(5.7)$ & $2.9(6.2)$ \\
& $\mathrm{G} 1$ & $19.4(30.1)$ & $7.7(15.3)$ & $4.1(8.9)$ & $2.1(4.1)$ \\
& G2 & $15.3(19.1)$ & $5.9(9.7)$ & $1.5(1.4)$ & $1.1(1.2)$ \\
\hline
\end{tabular}

Changes in plasma hormone concentrations every 2 hours for Group G0, Group G1, and Group G2. Results are expressed as the mean (SD). Differences among the three groups were not significantly different.

and $\mathrm{G} 1$ from T2-T6 $(P<0.01$ between $\mathrm{G} 0$ and $\mathrm{G} 2$ and between $\mathrm{G} 1$ and $\mathrm{G} 2$ at T2, T4, and T6; Figure 5); however, the plasma glucose level did not differ among the three groups at POD1. The frequencies of postoperative complications did not differ significantly among the three groups (Table 3).

\section{Discussion}

In this study, we investigated the effects of intraoperative glucose administration on metabolism under general anaesthesia maintained with remifentanil. We demonstrated that the intraoperative administration of glucose inhibits lipolysis 


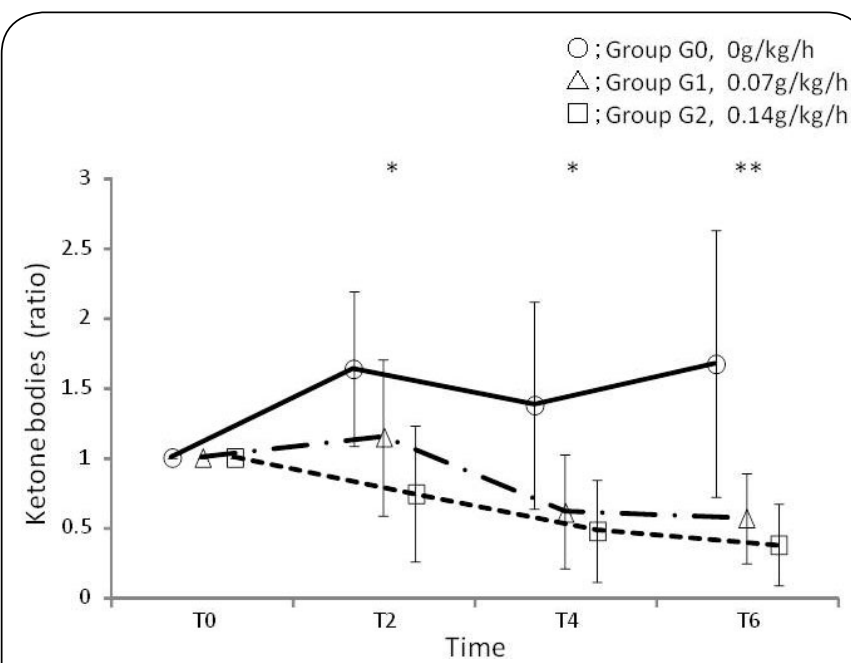

Figure 1. Changes in the plasma ketone bodies concentration relative to the value at T0 for Group G0, Group G1, and Group G2 at T0, T2, T4, and T6. The results are expressed as the mean \pm SD. Differences among the three groups were significant at $\mathrm{P}<0.001$ using a two-way repeated measure ANOVA. ${ }^{\star} \mathrm{P}<0.01$ among G0 and G2, G0, and G1; ${ }^{\star *} \mathrm{P}<0.001$ between G0 and G2, and between G0 and G1 using the Tukey test.

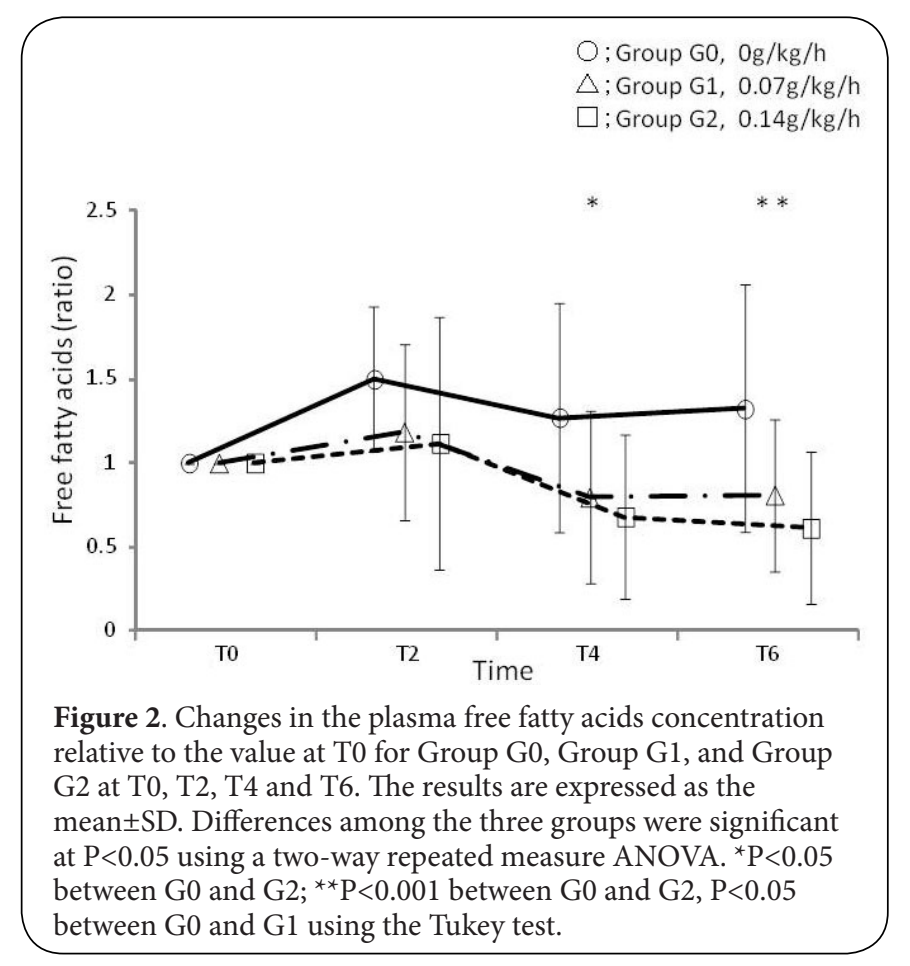

and proteolysis under general anaesthesia. In addition, our findings suggested that the optimal amount of glucose administration in our setting was $0.07 \mathrm{~g} / \mathrm{kg} / \mathrm{h}$, whereas more than $0.14 \mathrm{~g} / \mathrm{kg} / \mathrm{h}$ might cause hyperglycaemia (>160 mg/dl).

Glucose is essential for living bodies, and erythrocytes, adrenomedullary cells, and central nervous system cells

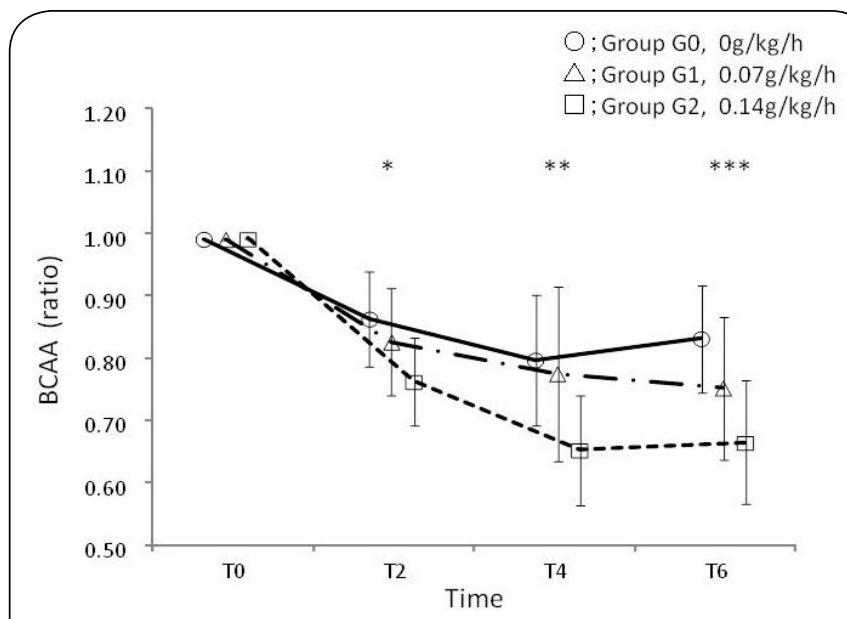

Figure 3. Changes in the BCAA concentration relative to the value at T0 for Group G0, Group G1, and Group G2 at T0, T2, $\mathrm{T} 4$, and T6. The results are expressed as the mean $\pm \mathrm{SD}$. Results are expressed as mean \pm SD. Differences between three groups were significant at $\mathrm{p}<0.001$ by a two-way repeated measure ANOVA. ${ }^{*} \mathrm{P}<0.05$ between $\mathrm{G} 0$ and $\mathrm{G} 2$; ${ }^{*} \mathrm{P}<0.001$ between $\mathrm{G} 0$ and G2, G1 and G2; ${ }^{* *} \mathrm{P}<0.001$ between G0 and G2, $\mathrm{P}<0.05$ between $\mathrm{G} 1$ and G2 by Tukey test.

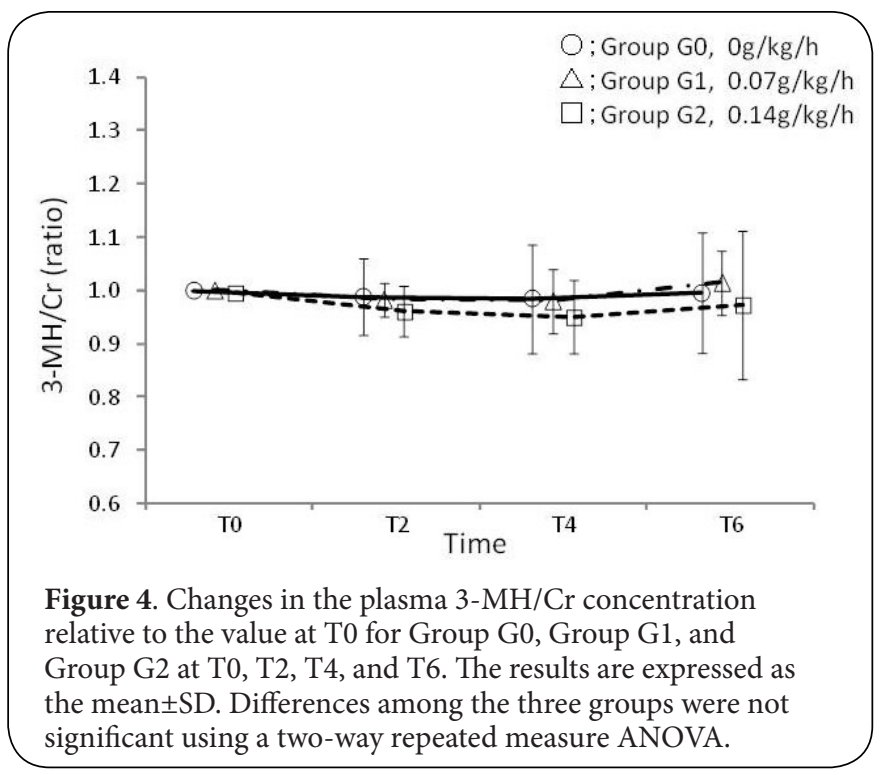

absolutely require $180 \mathrm{~g}$ of glucose per day [15]. A lack of glucose results in gluconeogenesis or fat and protein catabolism. The enhanced recovery after surgery (ERAS) program has suggested that perioperative nutritional care (avoidance of fasting, preoperative carbohydrate loading until 2 hours prior to surgery, and postoperative early enteral nutrition) can inhibit catabolism and improve insulin resistance [16]. In our study, the indexes of fat and protein catabolism of Group G0 were higher than those of other groups.

Previous studies have demonstrated the inhibition of catabolism by the administration of glucose under general 


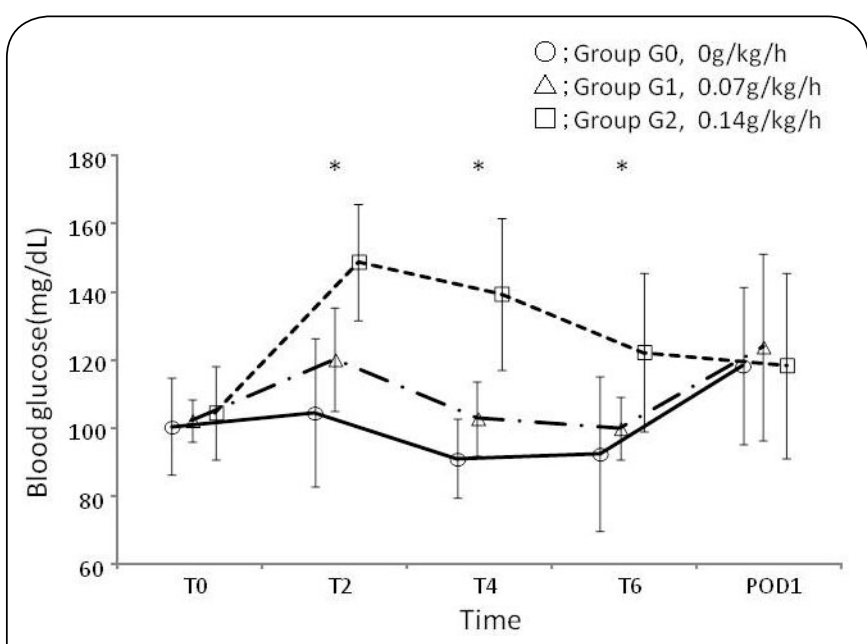

Figure 5. Changes in the plasma glucose concentration for Group G0, Group G1 and Group G2 at T0, T2, T4, T6, and POD1 (the following morning at $7 \mathrm{AM}$ ). The results are expressed as the mean \pm SD. Differences among the three groups were significant at $\mathrm{P}<0.001$ using a two-way repeated measure ANOVA. ${ }^{*} \mathrm{P}<0.01$ between G0 and G2, and between G1 and G2 using a Tukey test.

Table 3. Postoperative complications.

\begin{tabular}{llll}
\hline & Group G0 & Group G1 & Group G2 \\
\hline PONV & 7 & 11 & 5 \\
Surgery site infection & 2 & 3 & 1 \\
\hline
\end{tabular}

Values are given as the mean (SD) or number.

No significant differences were observed among the groups.

anaesthesia at a rate of $0.07-0.25 \mathrm{~g} / \mathrm{kg} / \mathrm{h}$ [1-7], whereas hyperglycaemia was detected in studies in which more than 0.15 $\mathrm{g} / \mathrm{kg} / \mathrm{h}$ of glucose were administered. We demonstrated that the mean energy expenditure $(\mathrm{EE})$ value of operative patients was $17.7 \mathrm{kcal} / \mathrm{kg} /$ day in a previous study [17]. As carbohydrates typically account for $50 \%$ of the energy provided by the three major nutrients, the above result suggests that patients under general anaesthesia require about $0.09 \mathrm{~g} / \mathrm{kg} / \mathrm{h}$. Therefore, we considered that the administration of less than $0.1 \mathrm{~g} / \mathrm{kg} / \mathrm{h}$ of glucose might provide a sufficient quantity of glucose without inducing hyperglycaemia and adopted a rate of $0.07 \mathrm{~g} / \mathrm{kg} / \mathrm{h}$ in this study; we then used a group treated with twice this amount $(0.14 \mathrm{~g} / \mathrm{kg} / \mathrm{h})$ as a target for comparison.

When examining the optimal amount of glucose to be administered and the effect of intraoperative glucose administration during general anaesthesia, one of the most important things is to consider the invasiveness of the surgery being performed. In most previous studies examining the effects of intraoperative glucose administration on metabolism, general anaesthesia was maintained with fentanyl without remifentanil and the type of surgery varied. Generally speaking, remifentanil is more useful for controlling intraoperative stress $[13,14]$. In addition, the anaesthetic drug that was used and the type of surgery that was performed both have large impacts on the extent of intraoperative stress. However, as mentioned above, the type of surgery performed differed in previous studies. Accordingly, surgical stress might not have been completely suppressed in the previous studies, which could have affected the subjects' plasma glucose levels. Since a variety of head and neck surgeries were included in our study, we measured stress indicators including adrenaline, noradrenaline, cortisol, and ACTH. However, no significant differences were observed among the three groups.

In previous studies, the plasma levels of ketone bodies and FFA were used to assess fat catabolism [1-7]. Similarly, we evaluated ketone bodies and FFA in the present study as well. On the other hand, the plasma BCAA, 3-MH, or 3-MH/Cr levels or urinary $3-\mathrm{MH} / \mathrm{Cr}$ levels were used to assess muscle catabolism [2-7]; in other words, the previous studies used different indexes. We used the plasma BCAA and 3-MH/Cr levels to assess muscle catabolism. The increase of BCAA levels observed during short fasting indicates a condition of protein catabolism [18]. The plasma 3-MH levels that have been corrected relative to the plasma creatinine levels have recently been suggested to be a more sensitive marker than the urinary 3-MH levels [19].

Despite the observed the inhibition of lipolysis (assessed by ketone bodies and FFA) and proteolysis (assessed by BCAA) in the absence of hyperglycaemia, the plasma 3-MH/Cr level did not differ significantly among the three groups. Yamasaki $\mathrm{K}$ et al. [5] showed that the plasma 3-MH level of a group in which glucose was administered $(0.07 \mathrm{~g} / \mathrm{kg} / \mathrm{h})$ after overnight fasting was significantly decreased after surgery. On the other hand, some studies have shown that the administration of glucose during surgery did not affect the urinary 3-MH or $3-\mathrm{MH} / \mathrm{Cr}$ levels $[3,6,7]$. Thus, Kanbe $\mathrm{N}$ et al. [7] proposed that 3-MH may not have been the most appropriate index of the degree of protein catabolism.

Our study had some limitations. First, compared with the currently recommended fasting period, the patients examined in this study were subjected to a long period of preoperative starvation. Thus, different results might be obtained in studies involving relatively short preoperative fasting periods. Second, since propofol was used for anaesthesia, an energy substrate was administered in Group G0. The amount of propofol administered was similar in all the groups; however, the administration of lipids alone might have influenced the metabolism in Group G0. Third, we did not evaluate the clinical outcomes. The inhibition of catabolism may promote the post operative outcomes, so that future large randomized trials are needed. Third, we could not observe the effects of glucose administration on postoperative complications. More patients were needed to analysis these outcomes. Further large-sized study is need in the future.

\section{Conclusion}

We evaluated the effects of administering different amounts 
of glucose on metabolism under general anaesthesia maintained with remifentanil. Our findings regarding the fat and protein catabolism indexes suggest that the administration of a low dose of glucose at a rate of $0.07 \mathrm{~g} / \mathrm{kg} / \mathrm{h}$ is adequate to suppress catabolism and to reduce the risk of hyperglycaemia.

\section{Competing interests}

The authors declare that they have no competing interests.

Authors' contributions

\begin{tabular}{|l|c|c|c|c|c|c|c|}
\hline Authors' contributions & SY & MT & NK & HH & TS & TA & KS \\
\hline Research concept and design & $\checkmark$ & -- & -- & -- & -- & -- & -- \\
\hline Collection and/or assembly of data & -- & $\checkmark$ & $\checkmark$ & $\checkmark$ & $\checkmark$ & -- & -- \\
\hline Data analysis and interpretation & -- & $\checkmark$ & $\checkmark$ & -- & $\checkmark$ & -- & -- \\
\hline Writing the article & $\checkmark$ & -- & -- & -- & -- & -- & -- \\
\hline Critical revision of the article & $\checkmark$ & -- & -- & $\checkmark$ & -- & $\checkmark$ & -- \\
\hline Final approval of article & $\checkmark$ & -- & -- & -- & -- & $\checkmark$ & $\checkmark$ \\
\hline Statistical analysis & $\checkmark$ & -- & -- & -- & -- & -- & -- \\
\hline
\end{tabular}

Acknowledgment

We thank Dr. Yoshihito Fujita for developing

the statistical analysis methods.

Publication history

EIC: D. John Doyle, Case Western Reserve University, USA.

Received: 29-Jun-2017 Final Revised: 14-Aug-2017

Accepted: 28-Aug-2017 Published: 12-Sep-2017

\section{References}

1. Sieber F, Smith DS, Kupferberg J, Crosby L, Uzzell B, Buzby G, March K and Nann L. Effects of intraoperative glucose on protein catabolism and plasma glucose levels in patients with supratentorial tumors. Anesthesiology. 1986; 64:453-9. | Article | PubMed

2. Obata K, Ogata M, Matsumoto T, Takenaka I, Sata T and Shigematsu A. The effects of glucose on plasma amino acids and pyruvate during upper abdominal surgery. Anesth Analg. 1993; 76:357-61. | Article | PubMed

3. Chambrier C, Aouifi A, Bon C, Saudin F, Paturel B and Bouletreau P. Effects of intraoperative glucose administration on circulating metabolites and nitrogen balance during prolonged surgery. J Clin Anesth. 1999; 11:64651. | Article | PubMed

4. Schricker $T$, Lattermann $R$ and Carli F. Intraoperative protein sparing with glucose. J Appl Physiol (1985). 2005; 99:898-901. | Article | PubMed

5. Yamasaki K, Inagaki Y, Mochida S, Funaki K, Takahashi S and Sakamoto S. Effect of intraoperative acetated Ringer's solution with $1 \%$ glucose on glucose and protein metabolism. J Anesth. 2010; 24:426-31. | Article | PubMed

6. Sawada A, Yoshikawa Y, Yamauchi M, Watanabe A and Yamakage M. [Breakdown of fat tissue and muscle protein under remifentanil anesthesia]. Masui. 2012; 61:358-63. | PubMed

7. Kambe N, Tanaka K, Kakuta N, Kawanishi R and Tsutsumi YM. The influence of glucose load on metabolism during minor surgery using remifentanil-induced anesthesia. Acta Anaesthesiol Scand. 2014; 58:948-54. | Article | PubMed

8. Fujino H, Itoda S, Esaki K, Tsukamoto M, Sako S, Matsuo K, Sakamoto E, Suwa K and Yokoyama T. Intra-operative administration of low-dose IV glucose attenuates post-operative insulin resistance. Asia Pac J Clin Nutr. 2014; 23:400-7. | Article | PubMed

9. Thorell A, Nygren J and Ljungqvist $O$. Insulin resistance: a marker of surgical stress. Curr Opin Clin Nutr Metab Care. 1999; 2:69-78. | Article | PubMed

10. Bilotta F, Giovannini F, Caramia R and Rosa G. Glycemia management in neurocritical care patients: a review. J Neurosurg Anesthesiol. 2009; 21:2-9. | Article | PubMed

11. Gelijns AC, Moskowitz AJ, Acker MA, Argenziano M, Geller NL, Puskas JD, Perrault LP, Smith PK, Kron IL and Michler RE et al. Management practices and major infections after cardiac surgery. J Am Coll Cardiol. 2014; 64:372-81. | Article | PubMed Abstract | PubMed FullText

12. Bower WF, Lee PY, Kong AP, Jiang JY, Underwood MJ, Chan JC and van Hasselt CA. Peri-operative hyperglycemia: a consideration for general surgery? Am J Surg. 2010; 199:240-8. | Article | PubMed

13. Winterhalter M, Brandl K, Rahe-Meyer N, Osthaus A, Hecker H, Hagl $\mathrm{C}$, Adams HA and Piepenbrock S. Endocrine stress response and inflammatory activation during CABG surgery. A randomized trial comparing remifentanil infusion to intermittent fentanyl. Eur $J$ Anaesthesiol. 2008; 25:326-35. | Article | PubMed

14. Shinoda T, Murakami W, Takamichi Y, lizuka H, Tanaka M and Kuwasako $Y$. Effect of remifentanil infusion rate on stress response in orthopedic surgery using a tourniquet application. BMC Anesthesiol. 2013; 13:14. Article | PubMed Abstract | PubMed FullText

15. Charles W. Nutrition and Metabolic control. IN: Ronald DM, Lars IE, Lee AF, Jeanine PW, William LY, eds. Miller's Anesthesia, 7th edition. Philadelphia: Churchill Livingstone. 2000; 2923-2956.

16. Gustafsson UO, Scott MJ, Schwenk W, Demartines N, Roulin D, Francis N, McNaught CE, MacFie J, Liberman AS, Soop M, Hill A, Kennedy RH, Lobo DN, Fearon $\mathrm{K}$ and Ljungqvist $\mathrm{O}$. Guidelines for perioperative care in elective colonic surgery: Enhanced Recovery After Surgery (ERAS(R)) Society recommendations. Clin Nutr. 2012; 31:783-800. | Article | PubMed

17. Yoshimura S, Fujita Y, Hirate H, Kusama N, Azami T and Sobue K. A short period of fasting before surgery conserves basal metabolism and suppresses catabolism according to indirect calorimetry performed under general anesthesia. J Anesth. 2015; 29:453-456. | Article | PubMed

18. Hammarqvist $F$, Andersson K, Luo JL and Wernerman J. Free amino acid and glutathione concentrations in muscle during short-term starvation and refeeding. Clin Nutr. 2005; 24:236-43. | Article | PubMed

19. Phillips GJ, Citron TL, Sage JS, Cummins KA, Cecava MJ and McNamara JP. Adaptations in body muscle and fat in transition dairy cattle fed differing amounts of protein and methionine hydroxy analog. I Dairy Sci. 2003; 86:3634-47. | Article | PubMed

\section{Citation:}

Yoshimura S, Tomita M, Kusama N, Hirate H, Sugiura T, Azami T and Sobue K. Administration of low dose of glucose suppresses catabolism under general anaesthesia maintained with remifentanil. J Anesthesiol Clin Sci. 2017; 6:4. http://dx.doi.org/10.7243/2049-9752-6-1 